\title{
Use of Satellite Imagery for Pastoral Resources Monitoring in Kossi Province (Burkina Faso)
}

\author{
Sieza Yssouf \\ Ministère des Ressources Animales et Halieutiques du Burkina Faso, Boucle du Mouhoun, \\ Burkina Faso \\ Gomgnimbou P. K Alain \\ Institut de l'environnement et de recherches agricoles (INERA) Station de Farako-Bâ, \\ Burkina Faso \\ Belem Adama \\ Ministère des Ressources Animales et Halieutiques du Burkina Faso, Boucle du Mouhoun, \\ Burkina Faso \\ Serme Idriss \\ Institut de l'environnement et de recherches agricoles (INERA), Burkina Faso
}

Received: Mar. 11, 2019

doi:10.5296/jas.v7i2.14475
Accepted: Mar. 27, 2019 Published: Apr. 7, 2019

URL: https://doi.org/10.5296/jas.v7i2.14475

\begin{abstract}
In Burkina Faso, livestock sector has an important place in the country's economy. Essentially extensive, this livestock farming is characterized by transhumance system, which consists of leading livestock sometimes over long distances in search of good pastures and water.

Satellite images from different periods can be used to monitor the evolution of pastoral resources (pasture areas and surface water points) in a given area. Field data, coupled with satellite images, provide a better understanding of livestock transhumance movements in the study area. The objective of this study was to monitor the spatial and temporal evolution of pastoral resources using remote sensing tools in Kossi province. Field data, coupled with satellite images, provide a better understanding of livestock transhumance movements in the study area.
\end{abstract}

Keywords: Burkina Faso, transhumant livestock farming, monitoring of pastoral resources, remote sensing, MODIS 


\section{Mll Macrothink}

\section{Introduction}

Burkina Faso is an agropastoral country whose livestock is one of the key sectors of its economy. With a livestock population numerically estimated in 2017 at 9.6 million cattle, 22 million small ruminants, 40.5 million poultry and 2.5 million pigs (DGESS/MRAH, 2018), the livestock sector contributes more than $15 \%$ to Burkina's GDP, 30\% to export earnings and $12 \%$ to value added formation (MRA, 2009).

More than $80 \%$ of domestic ruminant livestock production is conducted according to the transhumant or sedentary pastoral system (MRA/IEPC, 2005). Therefore, mobility appears to be the fundamental element of herd management in this type of farming.

In addition, Burkina Faso, like most countries in sub-Saharan Africa, is under great pressure and is suffering from the degradation of its natural resources (MECV/SP-CNDD, 2016). The consequence is a decrease in pastoral resources while the livestock system is extensive with high herd mobility.

This pastoral mobility is an adaptation to the spatial and temporal distribution of rainfall. It is the cornerstone of successful pastoral systems (Hiernaux et al., 2014; Niamir-Fuller, 1999; Scoones, 1994). Monitoring of pastoral resources is essential to understand pastoral mobility on a small geographical scale.

In the context of monitoring pastoral resources, remote sensing provides irreplaceable assistance (Richard \& Gérard, 2016). It is a major source of information for calculating environmental indicators, providing access to physical information such as albedo, vegetation indices, surface roughness, surface temperature or soil moisture.

The correlation between the rainfall gradient and the forage gradient can be reported by the standardized vegetation index (NDVI). It is a very common index used in remote sensing to measure vegetation density and health (Herring \& Weier, 2000). It is based on the fact that healthy vegetation absorbs visible light (due to chlorophyll synthesis) and reflects near-infrared radiation. The NDVI is therefore a synthetic index that gives an idea of the state of grazing in time and space (Anyamba \& Tucker, 2005).

This study is part of the overall framework of integrated natural resource management and aims to monitor the spatial and temporal evolution of pastoral resources using remote sensing tools. 


\section{Materials and Methods}

\section{Study site}

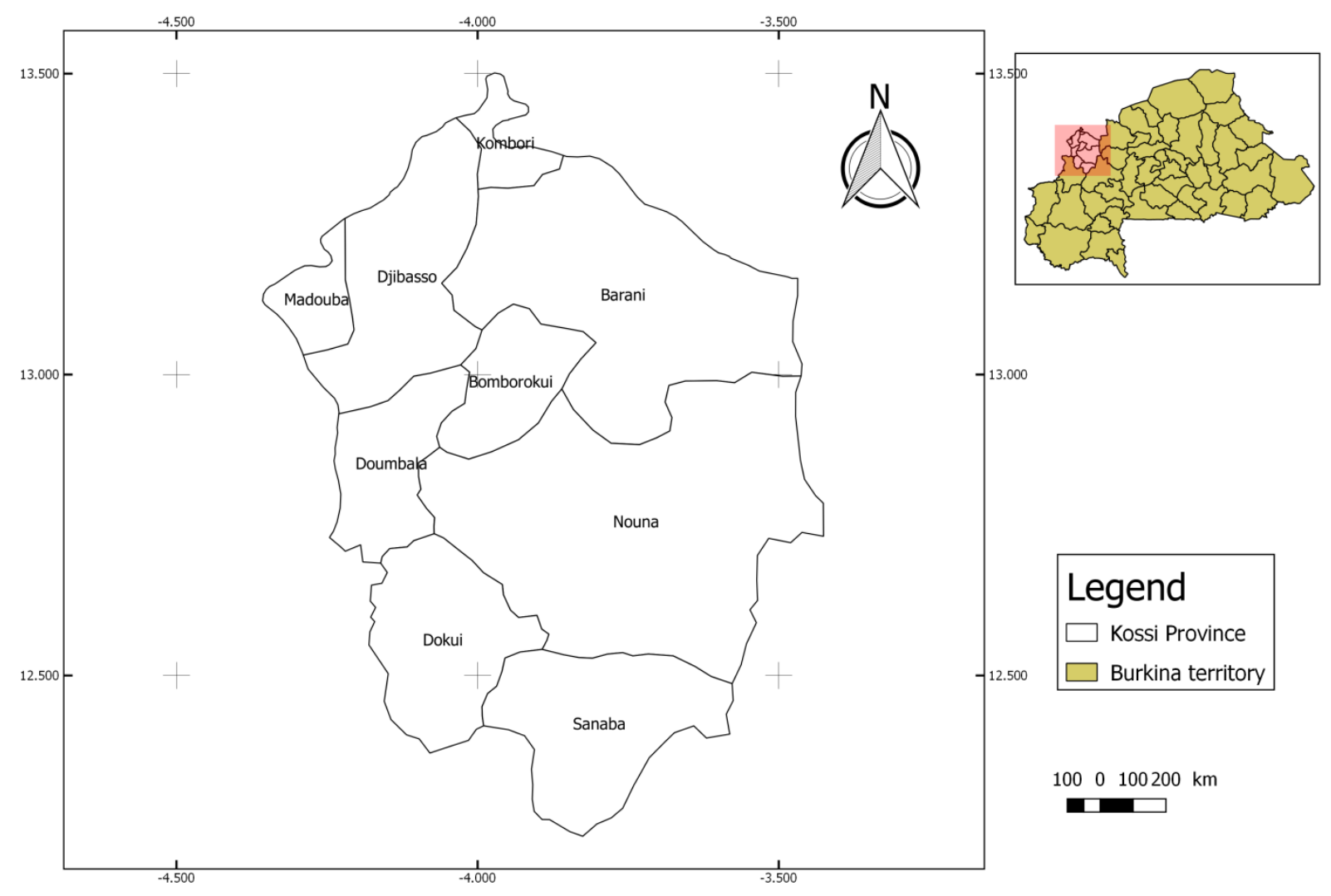

Figure 1. Study area location

This study was conducted in Kossi province (Figure 1), which has a population of 278,546 (INSD, 2008). 92\% of the population lives in rural areas, and lives mainly from agriculture and livestock. The study area is located at $12^{\circ} 55^{\prime} 0$ ' $\mathrm{N}$ latitude and $3^{\circ} 49^{\prime} 60^{\prime \prime} \mathrm{W}$ longitude.

A steppe climate is present in Kossi. Throughout the year, there is little rainfall. This location is classified as Hot steppe climate (BSh) by Köppen and Geiger (1928). The area has an average temperature of $28.1^{\circ} \mathrm{C}$ throughout the year. Annual rainfall average $748 \mathrm{~mm}$.

\section{Data acquisition and analysis}

In this study two types of data have been used: field data and satellite data.

The field data mainly concern data on livestock transhumance movements. These data are mainly derived from the monthly statistical reports of the Regional Office of Animals and Fisheries Resources of the Boucle du Mouhoun region. For this study, data from January to December 2017 were used. The parameters studied concerned the departure and return dates of transhumance, the causes of departure in transhumance and the destinations.

The 2017 time series of medium spatial resolution $(250 \mathrm{~m})$ remote sensing images used in this work are from the MODIS Terra and Aqua sensor (Giglio \& al., 2016). 


\section{I Macrothink}

Journal of Agricultural Studies

ISSN 2166-0379 2019, Vol. 7, No. 2

The vegetation cover of the study area is freely accessible on the website http://pekko.geog.umd.edu/usda/test/.

The product Modis burned areas (MOD09A1, Collection 6) used is from $\mathrm{ftp}: / /$ ba1.geog.umd.edu/.

The climate data used are from the FAO website http://dataviz.vam.wfp.org/. We were interested in the correlation between precipitation and vegetation index (Herrmann \& al., 2005).

QGIS 2.18.3 software was used for mapping production.

\section{Results and Discussions}

\section{Results}

Evolution of the vegetation cover

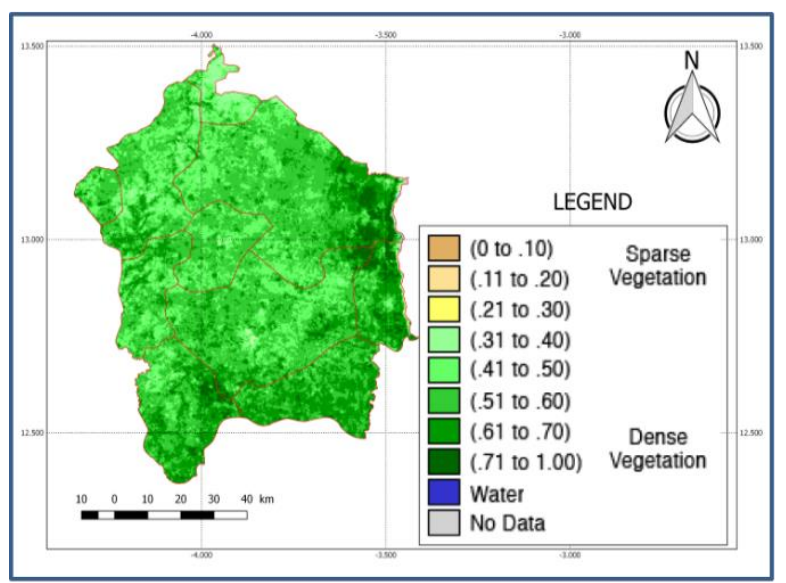

(a)

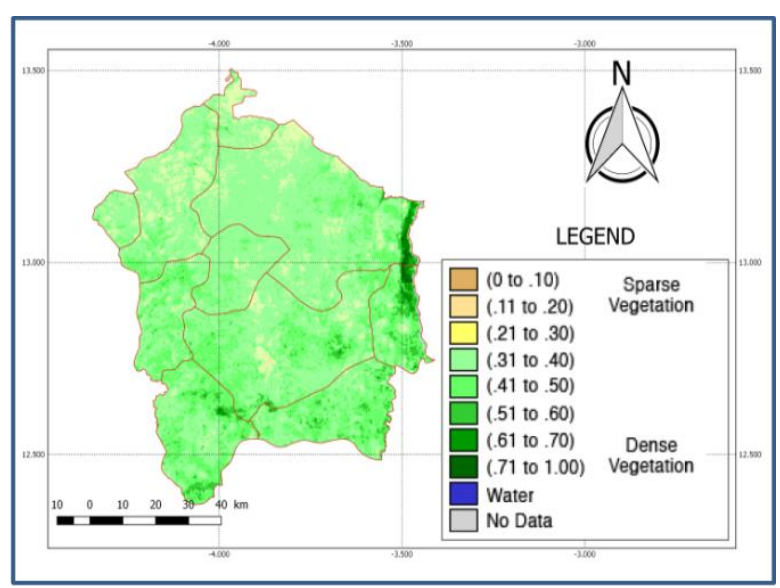

(b)

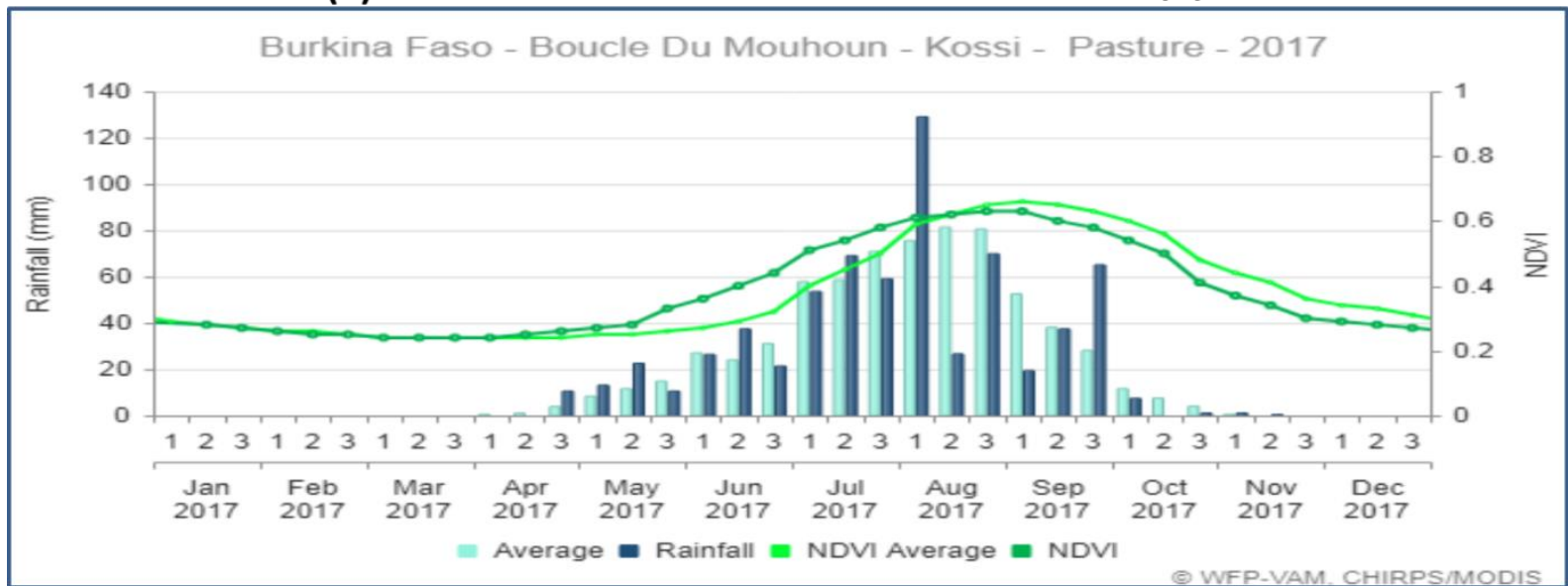

(c)

Figure 2. Annual vegetation dynamics

Figure 2 shows the evolution of the NDVI in relation to precipitation. The analysis of this figure (2c) makes it possible to distinguish three phases of evolution of the NDVI. 


\section{Macrothink}

The $3^{\text {rd }}$ dekad of November to the $2^{\text {nd }}$ dekad of April is the time when the NDVI is lowest in the study area, i.e. the time when the vegetation is driest. With the arrival of the very first rains, the vegetation begins to regreen in May. In the second dekad of July, the rainy season is well established throughout the area, everywhere the vegetation has entered its full production phase. Seeding starts to grow, further increasing the NDVI index. A peak is observed until the second dekad of October when a sharp drop in the NDVI graph is observed. It ranged from 0.54 in the $1^{\text {st }}$ dekad of October to 0.3 in the $3^{\text {rd }}$ dekad of November. During this same period, i.e. within two months, there was a remarkable change in the degradation status of the vegetation cover (Figures $2 \mathrm{a}$ and $2 \mathrm{~b}$ ).

\section{Bushfire practice and burned area}

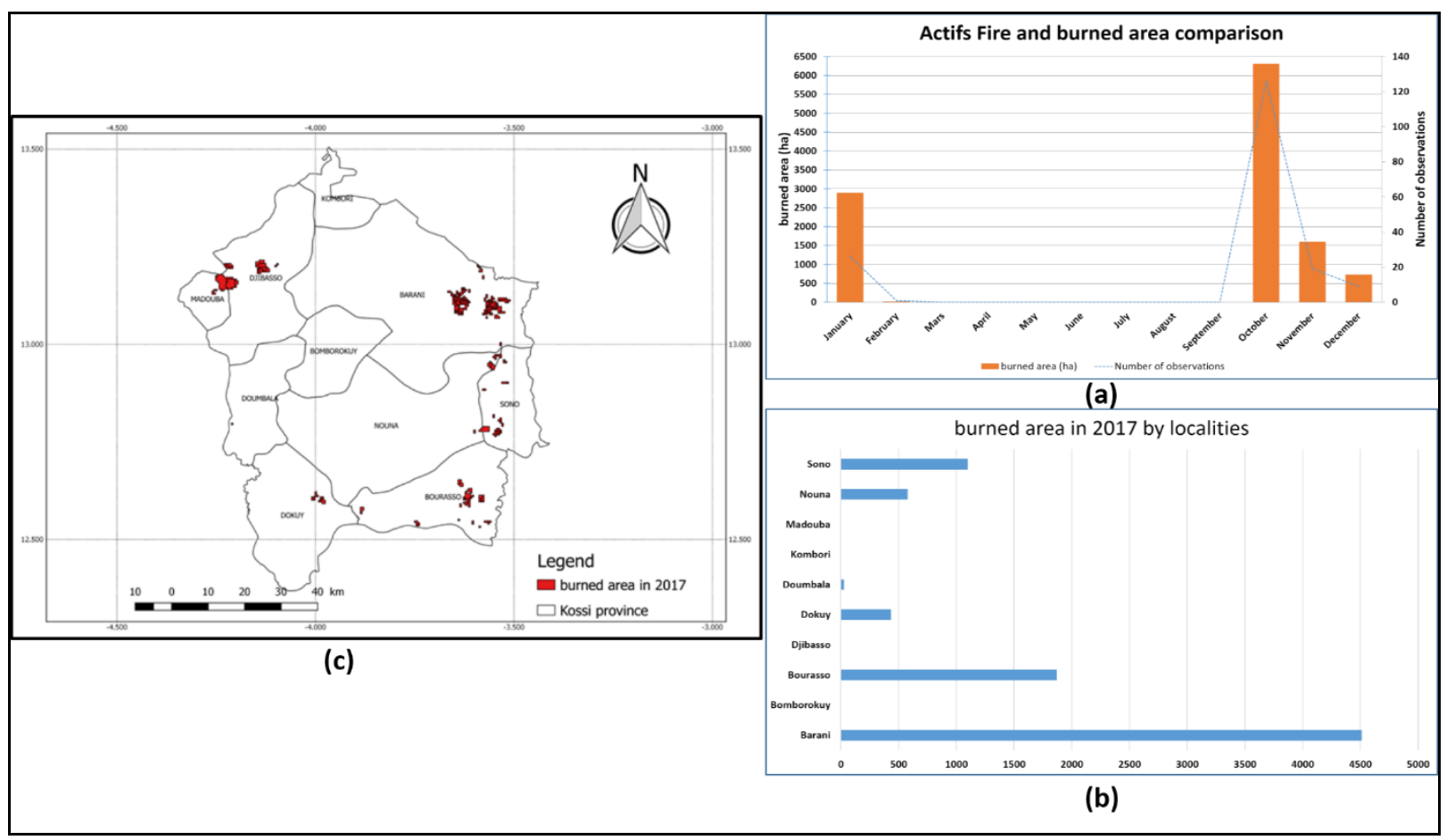

Figure 3. Annual dynamics of bushfires

Figure 3 shows the frequency of bushfires at the provincial level (3a), and the areas affected by these fires during the year at the provincial level and by municipalities in the province (3b). The analysis of the figure shows that the fires occurred for four (04) months in Kossi province. These are January, October, November, and December. October records the highest number of fires (126 points) over an area of about 6311.23 ha. The lowest number of appearances (09 points over an area of 736.85 ha) is recorded in December.

At the municipal level, it appears that the municipality of Barani has the largest area (4510.32 ha) affected by bushfires, followed by the municipalities of Bourasso and Sono respectively (Figure 3c). However, no evidence of bushfires was found in the communes of Bomborokuy, Djibasso, Doumbala, Kombori and Madouba. 


\section{Seasonal movement of livestock}

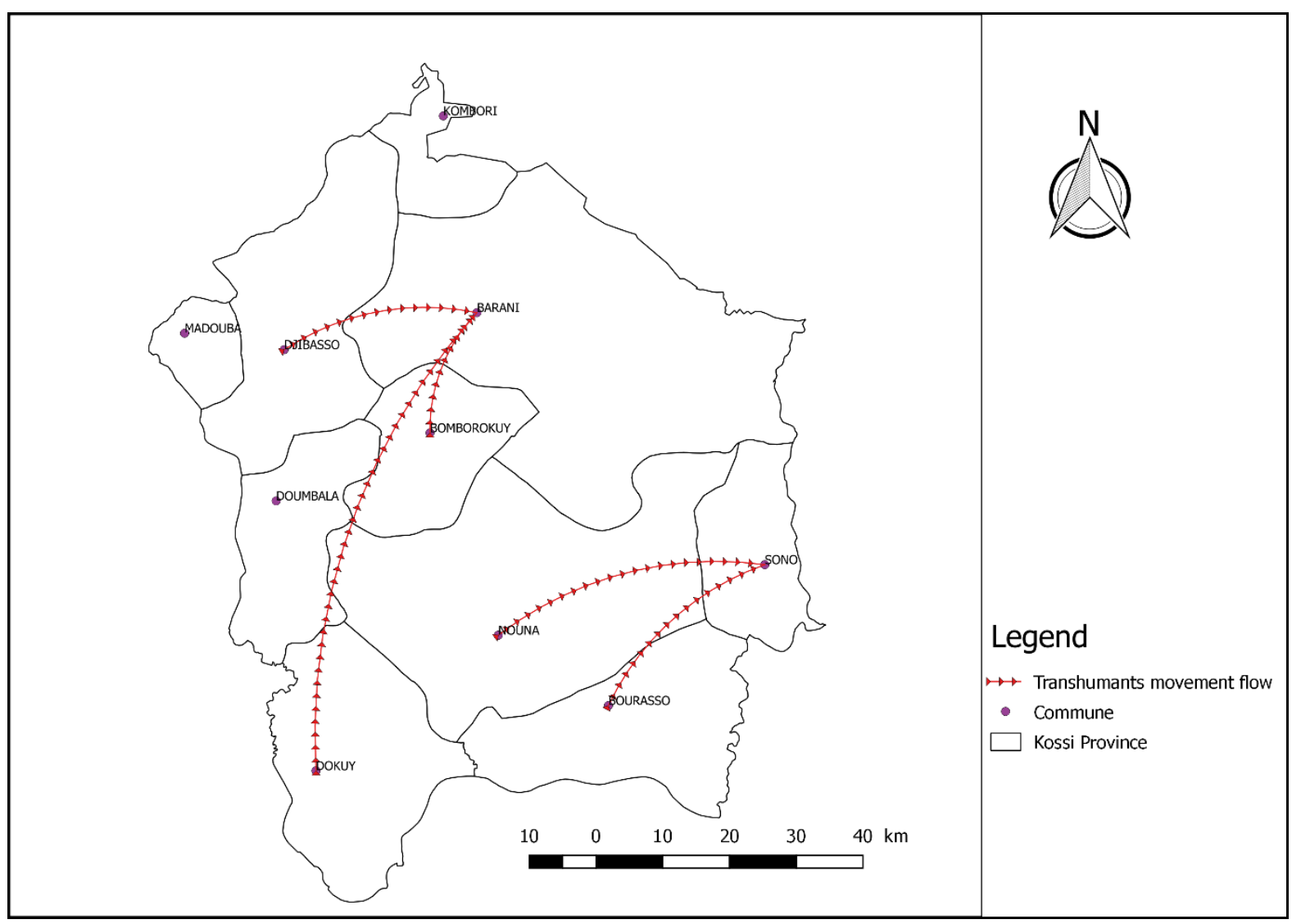

Figure 4. Livestock transhumance movements

The movement of livestock through provincial space and time is shown in Figure 4. The communes of Sono and Barani are the main transhumant hosting areas.

The analysis of the figure 5 shows two types of livestock transhumance movements during the study period. These are the internal movement of livestock on the one hand, and the reception of Malian transhumant in the areas of Sono, Barani and Bomborokuy to a lesser extent. 


\begin{tabular}{|l|l|l|l|l|l|l|l|l|l|l|l|l|l|l|}
\hline & Jan & Feb & Mar & Apr & May Jun & Jul & Aug & Sep & Oct & Nov & Dec \\
\hline Barani & & & & & & & & & & & & \\
\hline Bomborokuy & & & & & & & & & & & & \\
\hline Bourasso & & & & & & & & & & & & \\
\hline \hline Jjibasso & & & & & & & & & & & & \\
\hline Dokuy & & & & & & & & & & & & \\
\hline Doumbala & & & & & & & & & & & & \\
\hline Kombori & & & & & & & & & & & & \\
\hline Madouba & & & & & & & & & & & & \\
\hline Nouna & & & & & & & & & & & & \\
\hline Sono & & & & & & & & & & & & & \\
\hline
\end{tabular}

Figure 5. Livestock transhumance period

It should also be noted that transhumance movements are carried out in all municipalities except Doumbala, Kombori and Madouba. The first transhumance departures are observed in October in the commune of Dokuy, and transhumance returns are observed in April.

\section{Discussion}

There is a dynamic in livestock mobility in Kossi province and this would be linked to the search for pastoral resources to meet the food needs of animals (Gunter \& Philippe, 2006; Lhoste, 2007). Indeed, three types of livestock movements are observed in the province of Kossi, namely the departure of animals from the transhumant area, their return from transhumance and the arrival of animals from elsewhere in search of pasture in the area.

The departure of animals from Kossi province for transhumance is frequent from November to March. This could be explained by the absence or cessation of rains and therefore by a gradual degradation or decrease in pastoral resources (grasses, water). Crop residues, which would be one of the main sources of fodder at this time, could retain livestock (FAO, 2014). But if there are movements of farmers with their herds, it is because they feel they can earn better elsewhere to meet the food needs of their animals (Gunter \& Philippe, 2006). In addition, according to the results of the study, the period of appearance of bushfires corresponds to the period of departure of animals on transhumance. There was also a significant degradation of the vegetation cover and therefore a decrease in forage potential from October to November in the locality. This could further justify these departures in transhumance of livestock farmers during this period (Kiema, Ghislain, \& Nouhoun, 2014).

The animals return from transhumance mainly in April and June. They are currently benefiting from herbaceous regrowth following the first rains. They will remain in the area throughout the rainy season to enhance the value of green fodder.

In addition to the departure and return of transhumance, the Kossi provincial territory records 
the arrival of foreign livestock for the development of forage resources. This is the specific case of the municipalities of Sono, Bomborokuy and Barani, which are the host municipalities for transhumants. These animals arrive mainly after the harvests (November, December, January). The objective of these transhumants would be to enhance the value of fodder resources, in particular crop residues in these reception areas (Hiernaux, Mamadou, \& Fabrice, 2014). These areas could attract transhumants through the presence of a pastoral area (Barani) and a permanent watercourse (Barani and Sono) that would play an important role in livestock watering. Moreover, from the analysis of bushfires, it appears that the municipality of Barani has the largest area burned, followed by Bourasso and Sono. These fires could then be linked to pastoral activities; i.e. fires caused by herders to stimulate the regeneration of certain herbaceous plants, particularly perennial grasses, in order to improve the nutritional value of the pasture (Granier \& Cabanis, 1976). According to the same authors, since fodder in the dry season is low in carotene and nitrogen, farmers are trying to fill this gap with the young grasses obtained after the fire.

The time series of Modis images allow us to understand the evolution of pastoral resources in time and space. However, they do not allow livestock services to direct transhumants at any given time on the route to be followed. As such, another Modis product is better suited. These are the images of Modis real-time. These images make it possible to follow the evolution of an event in a given area almost in real time. This will make it possible to adequately distribute the burden of livestock on the territory on the one hand, and to avoid conflicts related to the movement of livestock on the other hand.

\section{Conclusion}

The objective of this study was to monitor the spatial and temporal evolution of pastoral resources in Kossi using remote sensing tools. The use of the time series of modis images allowed to follow the evolution of the vegetation cover on the one hand, and then to understand bushfire practices and burned surfaces on the other hand. Field data, coupled with satellite images, provide a better understanding of livestock transhumance movements in the study area. At the end of this study, we can therefore say that the use of satellite images of different periods can make it possible to monitor the evolution of pastoral resources (pasture areas and surface water points) in a given area, which is an easy, less costly and faster way to produce maps of the spatial and temporal evolution of pastures. These will be a valuable decision-making tool for all actors in pastoralism. Knowing that herd mobility is the major characteristic of pastoral livestock farming. Remote sensing tools can enable sustainable management of pastoral resources through adequate monitoring and rational spatial distribution of the herd. 


\section{References}

Anyamba, A., \& Tucker, C. (2005). Analysis of Sahelian Vegetation Dynamics Using NOAA-AVHRR NDVI Data from 1981-2003. Journal of Arid Environments, (63). 596-614. https://doi.org/10.1016/j.jaridenv.2005.03.007

Boutrais, J. (1994). Pour une nouvelle cartographie des Peuls. Cahiers d'études africaines, 137(46). https://doi.org/10.3406/cea.1994.2044

DGESS/MRAH. (2018, Fevrier 14). projection effectifs du cheptel 2020. Series statistiques.

FAO. (2014). Résidus agricoles et sous-produits agro-industriels en Afrique de l'ouest: Etat des lieux et perspectives pour l'élevage. Rome.

Giglio, L., Schroeder, W., \& Justice, C. O. (2016). The collection 6 MODIS active fire detection algorithm and fire products. Remote Sensing of Environment, 178, 31-41.

https://doi.org/10.1016/j.rse.2016.02.054

Granier, P., \& Cabanis, Y. (1976). Les feux courants et l'élevage en savane soudanienne. Revue d'élevage et de médecine vétérinaire des pays tropicaux, 29(3), 267-275. https://doi.org/10.19182/remvt.8026

Gunter, S., \& Philippe, M. (2006). Les conflits liés à la transhumance transfrontalière entre le Niger, le Burkina Faso et le Bénin.

Herring, D., \& Weier, J. (2000). Measuring Vegetation (NDVI and EVI). Nasa Earth Observatory. Récupéré sur.

http://earthobservatory.nasa.gov/Features/MeasuringVegetation/measuring_vegetation_2.php

Herrmann, S. M., \& Anyamba, A., \& Tucker, C. J. (2005). Recent trends in vegetation dynamics in the African Sahel and their relationship to climate. Global Environmental Change, 15(4), 394-404. https://doi.org/10.1016/j.gloenvcha.2005.08.004

Hiernaux, P., Mamadou, D., \& Fabrice, G. (2014, Août 26). Quelle accessibilité aux ressources pastorales du Sahel ?L'élevage face aux variations climatiques et aux évolutions des sociétés sahéliennes. Afrique contemporaine, 1(249), 21-35. https://doi.org/10.3917/afco.249.0021

INSD. (2008). Recensement Générale de la Population et de l'Habitat de 2006 (RGPH-2006). Récupéré sur. http://www.insd.bf/documents/publications/insd/publications/resultats_enquetes/autres enq/Resultats_definitifs_RGPH_2006.pdf

Kiema, A., Ghislain, B., \& Nouhoun, Z. (2014, Décembre 27). Transhumance et gestion des ressources naturelles au Sahel : contraintes et perspectives face aux mutations des systèmes de productions pastorales. VertigO, 14(03).

Köppen, W., \& Geiger, R. (1928). Die klimate der Erde. Wall-map 150cmx200cm. Gotha: Verlag Justus Perthes. 


\section{Macrothink}

Journal of Agricultural Studies

ISSN 2166-0379 2019, Vol. 7, No. 2

Lhoste, P. (2007). Sociétés pastorales et désertification au Sahel. Lutte contre la désertification sahel Bois et forêts des tropiques. 293(3), 49-59.

MECV/SP-CNDD. (2016). IVe Rapport sur l'Etat de l'Environnement au Burkina Faso. Ouagadougou.

MRA. (2009). Politique de Développement de l'Elevage au Burkina Faso 2010-2020. Ouagadougou.

MRA/IEPC. (2005). Document National/Initiative Elevage Pauvreté Croissance (IEPC). Ouagadougou.

Niamir-Fuller, M. (1999). Managing mobility in african rangelands. Food and Agricultural Organization and the Beijer International Institute of Ecological Economics, London. https://doi.org/10.3362/9781780442761

Richard, E., \& Gérard, B. (2016, Novembre). Surveiller la désertification par télédétection. Les dossiers thématiques du CSFD(12), p. 44.

Scoones, I. (1994). Living with uncertainty: new directions in pastoral development in Africa. Intermediate Technology Publications, London.

\section{Copyright Disclaimer}

Copyright for this article is retained by the author(s), with first publication rights granted to the journal.

This is an open-access article distributed under the terms and conditions of the Creative Commons Attribution license (http://creativecommons.org/licenses/by/4.0/). 